\title{
ANALYSIS OF THE FIRE-PROTECTION IMPREGNATION INFLUENCE ON WOOD STRENGTH
}

\author{
Zoja Bednarek $^{1}$, Agnieszka Kaliszuk-Wietecka ${ }^{2}$ \\ ${ }^{1}$ The Main School of Fire Service, ul. Stowackiego 52/54, Warsaw, Poland.E-mail: sgsp@sgsp.edu.pl \\ ${ }^{2}$ Warsaw University of Technology, al. Armii Ludowej 16, Warsaw, Poland. \\ E-mail: a.kaliszuk-wietecka@il.pw.edu.pl
}

Received 5 Oct 2005; accepted 19 Feb 2007

\begin{abstract}
The paper presents the description, results and result analysis for the effect of fire-protection impregnation with a salt-containing agent, made by a vacuum-and-pressure method, on wood strength. A significant effect of this impregnation type was proven for the strength types as follows: static bending, tension, lengthwise compression (ie along fibres), crosswise compression (ie across fibres), as well as for dynamic bending and impact strength in normal and elevated temperatures.
\end{abstract}

Keywords: wood, strength, elevated temperatures, preservation of fireproof, vacuum-pressure impregnation.

\section{Introduction}

The wood house construction sector is developing quickly at present. As a construction material, wood has a number of advantages such as good mechanical properties, but shows a low resistance against fire and high temperatures. This feature requires new methods to be developed in order to protect wood from the operation of fire and high temperatures.

There is a number of well-known protection methods: fire-proof insulation panels, fire-proof lacquers, and expanding coats to name just a few. Among those methods, impregnation with chemical agents, ie with impregnants, is widely applied. Pressure-less deep impregnation methods and high-pressure impregnation methods are recognised as the most effective because they provide better impregnance penetration results. The deep impregnation and the highpressure deep impregnation in particular provide much better results. High-pressure methods are widely applied in European countries; as many as 2 million cu m wood are protected a year in Germany alone.

A specific flaw of this method has been lately pointed at wood strength. Obligatory tests were introduced in many countries, also in Poland, in order to find out the effect of impregnation agents on wood strength.

Still, because of the impregnation method adopted and of a limited scope of strength tests, the method as described in the standard [1] does not always disclose the real impregnation effect.

An analysis of test results (tests made at the Zakład Mechaniki Stosowanej Szkoły Głównej Służby Pożarniczej - the Applied Mechanics Department of the Main School of Fire Service) was made in order to clear the effect of fire-protection impregnation with saltcontaining agents by a vacuum-and-pressure method.

\section{Analysis of the knowledge regarding the impregnation effect on wood strength}

More than a half of papers on fire-protection wood impregnation was devoted to the effect of impregnation for the flammability, inflammability, and carbonisation rate. Only a small number of papers deals with the effect of selected impregnants (as applied by one of the known methods) on wood strength, and shows the impregnant effect in trend graphs [2-10]. Results of those tests are not always unequivocal, and they are not always subject to statistical analysis due to a small number of samples. The above-mentioned tests were mainly aimed at impact strength, bending strength, and compressive strength [3, $4,6]$.

This direction was selected because the impact strength is the feature that quickly reacts to any change of a destructive character, but is also specific for its widespread test results, whereas the static bending strength means a small scatter of results. Therefore this strength type is frequently tested.

In order to sum up the current knowledge status, we should state:

- Almost all researchers indicate significant and different effects of the impregnation on wood strength.

A number of agents cause modifications of strength figures: strength can decrease between several percent and more than $20 \%$. Still, in some cases modification can be insignificant, or the effect can be even opposite, ie the compressive strength increases 


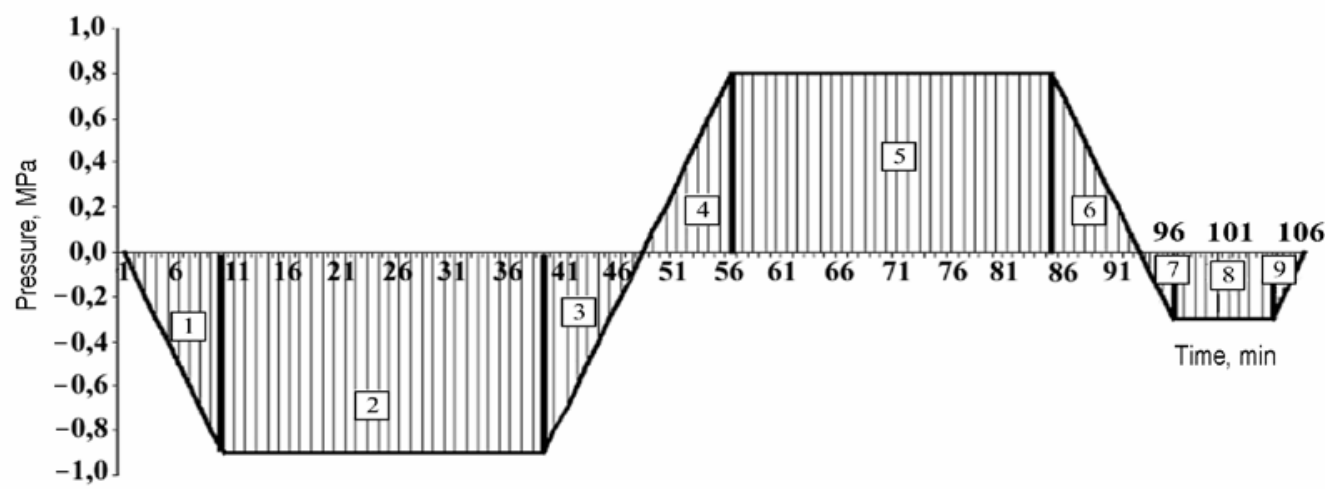

Fig 1. Saturation process with a salt-containing agent

- Impregnated wood is specific for its increased moisture content compared to non-impregnated wood, even in a long term,

- Impregnation methods and saturation make a significant effect on the impregnations agent influence character and extent of wood strength,

- The temperature increase was not accounted for tests presented in references.

\section{Objective and scope of the tests}

The test objective was to determine the vacuum-andpressure method (with a salt-containing agent) influence on wood strength under normal conditions, and when exposed to high temperatures in the course of impregnation treatment. The tests were of a comparative character. Test results for natural wood samples were compared against samples of impregnant-saturated wood.

The following strength types were subjected to tests: a) static tests:

- static bending tests,

- lengthwise compressive strength,

- crosswise compressive strength,

- lengthwise tension strength.

b) dynamic tests:

- impact strength,

- dynamic bending strength.

Comparative tests were planned and made for two basic sample groups:

- samples saturated with a water solution of a saltcontaining agent by the vacuum-and-pressure method,

- non-saturated samples featuring a natural structure.

Besides, a set of special samples was used; those samples were saturated with water by the vacuum-andpressure method.

A $20 \%$ solution of a fire-protection impregnation agent commonly used in Poland was applied for tests. This agent is a blend of: monobasic ammonium phosphate, dibasic ammonium phosphate, ammonium sulphate, urea, and boric acid. The saturation treatment is shown in Fig 1. After impregnating, all samples were stored for approx one year at constant temperature and humidity.
Static tests were made on special stands featuring sample heating as well as sample temperature control while testing. Circuits were connected with a computer which provided with a precision control for every test circuit and automatic recording of results as well. 25 samples were tested for each metering point. The total number of samples was:

- static bending strength tests: 360 samples,

- compressive strength tests: 360 cross-fibre samples, 360 along-fibre samples,

- along-fibre tensile strength tests: 360 samples,

- dynamic bending and impact strength tests: 190 samples.

The manufacture and preparation of samples for strength tests were given a high care. Samples were made from a defect-free pine log seasoned for 4 years [11].

\section{Experiment planning}

\section{a. Static tests}

Tests were based on the experiment plan as shown in Fig 2.

\section{INPUTDATA}

\section{OUTPUT DATA}

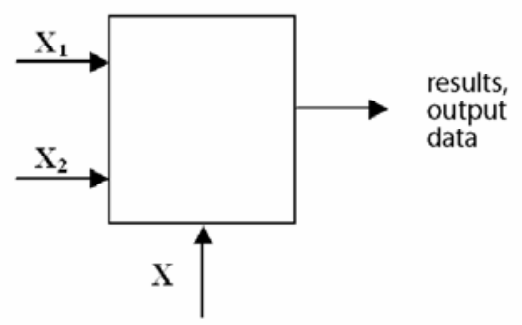

Fig 2. Experiment plan for static tests. Input data: $\mathrm{X}$ constant factors: wood species, moisture content, X1 - variable factors - saturation status: saturated $=1$, nonsaturated $=0, \mathrm{X} 2-$ variable factor: temperature during tests. Output data: static strength profiles

Samples saturated with the impregnate and nonsaturated samples were used for static tests. Tests were made at temperatures: $20,50,100,150,200,230^{\circ} \mathrm{C}$. The test points are shown in Fig 3. 


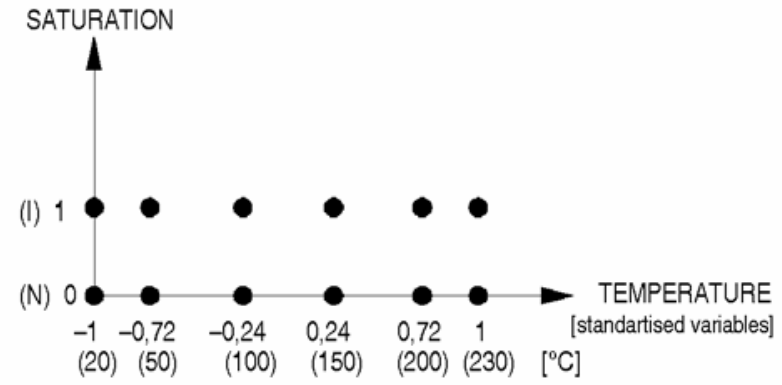

Fig 3. Test points for static tests tions.

Tests were made under the following thermal condi-

The starting temperature was assumed $20^{\circ} \mathrm{C}$.

The temperature limit (maximum) was $230^{\circ} \mathrm{C}$. This is close to the wood ignition temperature that requires approx $250{ }^{\circ} \mathrm{C}$. At the same time, this is the average temperature at which wood carbonisation starts and wood starts changing its physical and chemical properties. An intensive emission of combustion gases occurs at this temperature as well.

$100{ }^{\circ} \mathrm{C}$ is a significant temperature for the tests, as water evaporates at this temperature. Due to the energy amount required for evaporation, wood temperature in fire does not increase above $100{ }^{\circ} \mathrm{C}$ as along as wood releases humidity.

At $200{ }^{\circ} \mathrm{C}$ volatile substances commence releasing quickly from wood.

Temperatures of $50{ }^{\circ} \mathrm{C}$ and $150^{\circ} \mathrm{C}$ were selected the intermediate temperature values used for determining the strength variation trend.

Static tests were performed at 20, 50, 100, 150, 200, $230{ }^{\circ} \mathrm{C}[12,13]$.

Test samples were made compliant to standards [11, 14-17].

Due to the sample shapes and dimensions as required by standards, samples could be soaked with the impregnant uniformly.

Tests were made on special stands located inside the heating chambers [18]. Temperature was metered during tests with two thermoelements located on the sample surface. The time needed for holding samples at a constant temperature was determined during introductory tests. Samples were loaded only after the temperature achieved the same value across the sample.

\section{b. Dynamic tests} (Fig 4).

Dynamic tests were based on the experiment plan

For dynamic tests at normal temperature, an additional group of water-soaked samples was used; the soaking method was the same as for soaking with the impregnant. The test objective was to prove the wood destruction impact on strength as a result of the vacuum-and-pressure method only [19].
INPUTDATA

OUTPUT DATA

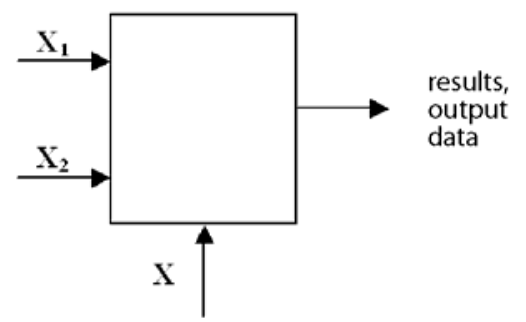

Fig 4. Experiment plan for dynamic tests. Input data: $\mathrm{X}-$ constant factors: wood species, moisture content, X1 - variable factors - saturation status: saturated $=1$, nonsaturated $=0$, water-saturated $=-1, \mathrm{X} 2$ - variable factor: temperature of thermal treatment before tests. Output data: dynamic strength

Test points were presented in Fig 5. As many as 25 samples were tested for each test point. Test samples were made according to the standard $[11,20]$. Because the dynamic test benches have no provisions for heating samples during tests, samples were thermally treated at $100{ }^{\circ} \mathrm{C}$ and $200{ }^{\circ} \mathrm{C}$ before tests. Then, tests were made at normal temperature.

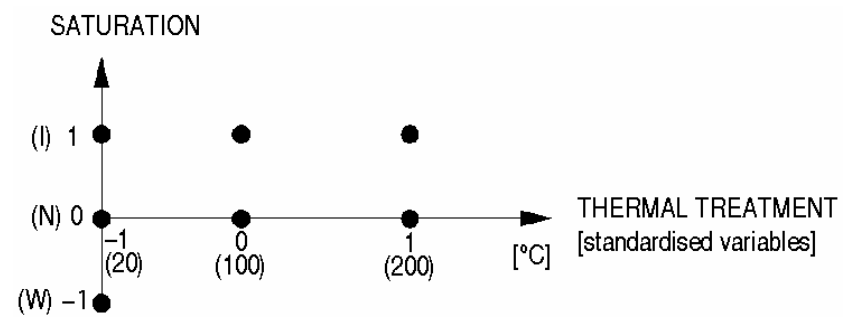

Fig 5. Test points for dynamic tests

\section{Test results}

Statistic calculations were made. The objective for the correlation and regression analysis was obtaining distribution curves for test results. The analysis results are shown in Figs 6-11. Y is the set of the arithmetic means from each wood strength profiles; $\mathrm{X}$ is the set of temperatures the tests were made at, or of temperatures of the thermal treatment (dynamic tests).

The statistical analysis allowed the determination of the mutual correlation between $\mathrm{X}$ and $\mathrm{Y}$, and the regression function type that approximated a certain set of points.

The summary of linear regression functions and of correlation coefficients is in Table.

Arithmetic mean values for test results were also marked in diagrams (Figs 6-11) as calculated on average of 25 measurements at each metering point.

Phenomena observed during the tests:

- Impregnated samples are getting brittle.

- Impregnated samples show a different fracture than non-impregnated samples: impregnated samples have smooth fractures, whereas non-impregnated fractures have frayed long-fibre fractures (Figs 12, 13). 


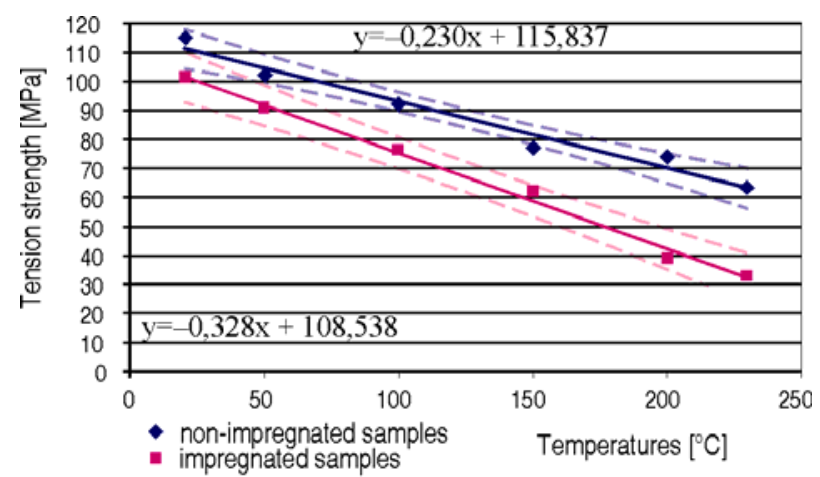

Fig 6. Tension strength vs temperature for impregnated and non-impregnated wood

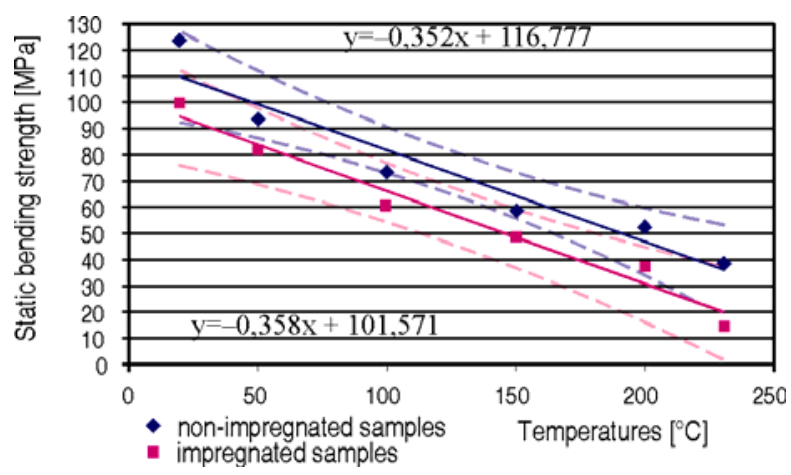

Fig 7. Static bending strength vs temperature for impregnated and non-impregnated wood

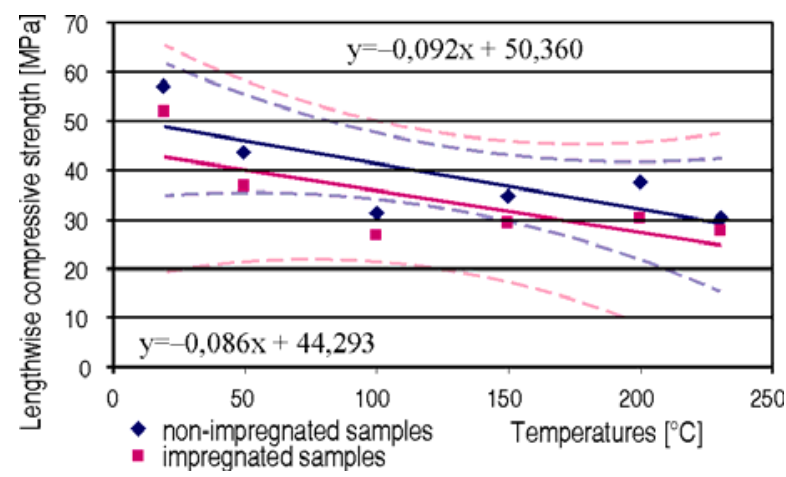

Fig 8. Lengthwise compressive strength vs temperature for impregnated and non-impregnated wood

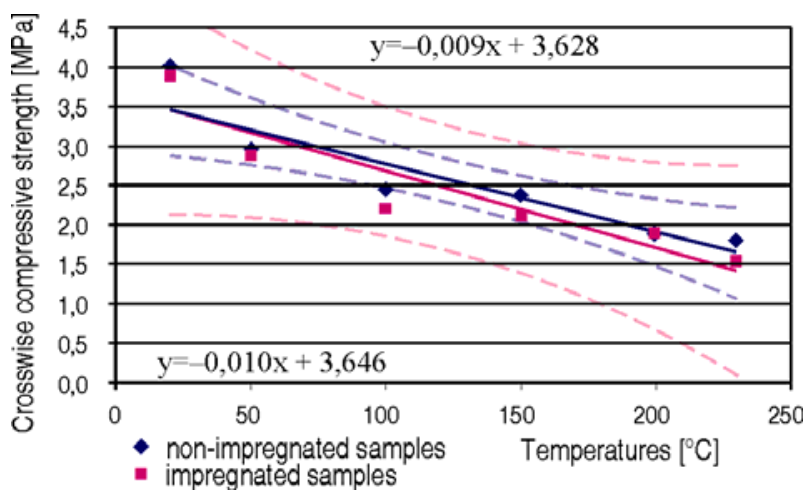

Fig 9. Crosswise compressive strength vs temperature for impregnated and non-impregnated wood

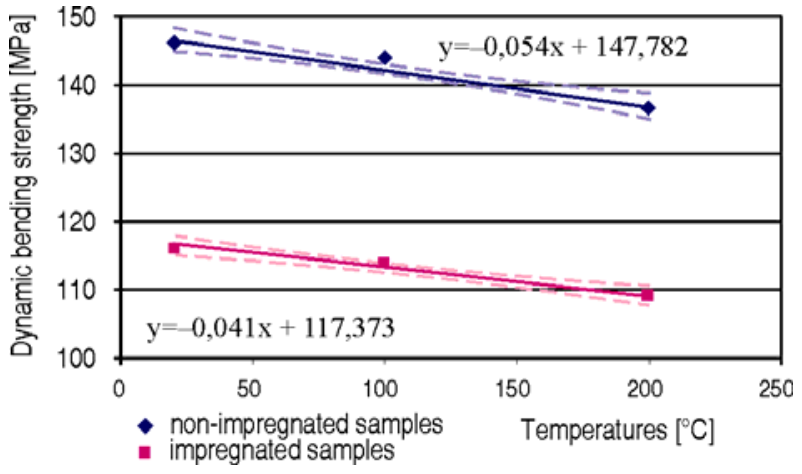

Fig 10. Dynamic bending strength vs. temperature for impregnated and non-impregnated wood

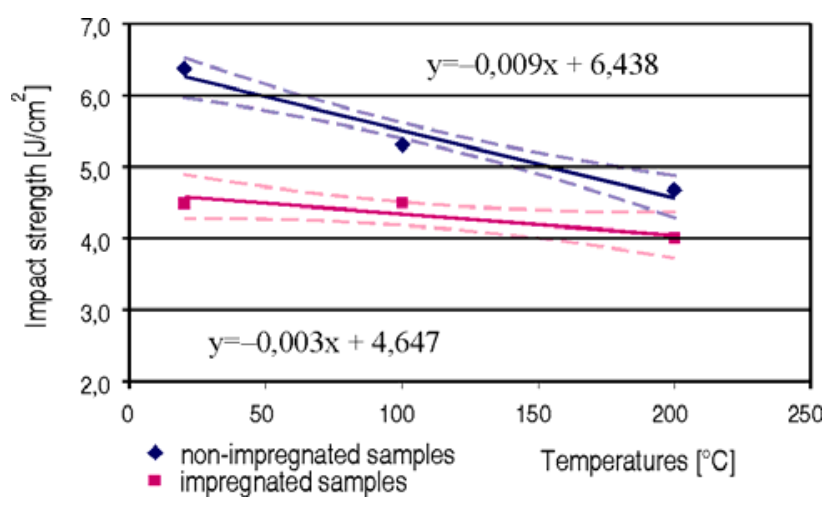

Fig 11. Impact strength vs temperature for impregnated and non-impregnated wood

- At approx $200{ }^{\circ} \mathrm{C}$, the impregnated samples are damaged due to the wood delamination and crushing, which do not occur in the non-impregnated samples (Fig 14).

After the analysis of test results we confirm that:

1. At the normal temperature $\left(20^{\circ} \mathrm{C}\right)$, the impregnation effects were:

- tension strength decreased by $12,4 \%$,

- static bending strength decreased by $19,8 \%$,

- lengthwise compression strength decreased by $8,9 \%$,

- crosswise compression strength increased by $3,25 \%$.

2. At $100{ }^{\circ} \mathrm{C}$ the following results were recorded:

- tension strength decreased by $16,4 \%$,

- static bending strength decreased by $17,1 \%$,

- lengthwise compression strength decreased by $14,7 \%$,

- crosswise compression strength decreased by $9,8 \%$.

3. For dynamic bending strength: tests at normal temperatures of samples without the thermal treatment and after such a treatment proved the strength to decrease by approx $20 \%$. Yet, for samples without a thermal treatment the impact strength lower by $30 \%$ was observed. 
Comparison of regression function formula coefficients and of correlation coefficients for each test type. $\mathrm{N}$ - natural samples. I - samples impregnated with the salt-containing agent by the vacuum-and-pressure method

\begin{tabular}{|c|c|c|c|c|c|c|c|}
\hline \multirow{4}{*}{ Item } & \multirow{4}{*}{ Test type } & \multicolumn{4}{|c|}{ Straight line equation coefficients } & \multirow{2}{*}{\multicolumn{2}{|c|}{$\begin{array}{l}\text { Regression coefficient } \\
\text { for the strength vs } \\
\text { temperature formula } \\
\text { Slope (a) }\end{array}$}} \\
\hline & & \multicolumn{2}{|c|}{ Slope (a) } & \multicolumn{2}{|c|}{ Intercept (b) } & & \\
\hline & & \multicolumn{2}{|c|}{ Sample sets } & \multicolumn{2}{|c|}{ Sample sets } & \multicolumn{2}{|c|}{ Sample sets } \\
\hline & & $\mathbf{N}$ & $\mathbf{I}$ & $\mathbf{N}$ & $\mathbf{I}$ & $\mathbf{N}$ & $\mathbf{I}$ \\
\hline 1 & TENSION & $-0,23$ & $-0,328$ & 115,84 & 108,54 & 0,9853 & 0,9962 \\
\hline 2 & STATIC BENDING & $-0,352$ & $-0,358$ & 116,78 & 101,58 & 0,9626 & 0,9861 \\
\hline 3 & LENGTHWISE COMPRESSION & $-0,092$ & $-0,086$ & 50,36 & 44,29 & 0,7667 & 0,7461 \\
\hline 4 & CROSSWISE COMPRESSION & $-0,009$ & $-0,010$ & 3,63 & 3,65 & 0,9347 & 0,9111 \\
\hline 5 & DYNAMIC BENDING & $-0,054$ & $-0,041$ & 147,78 & 117,37 & 0,9728 & 0,9900 \\
\hline 6 & IMPACT & $-0,009$ & $-0,003$ & 6,44 & 4,65 & 0,9766 & 0,9108 \\
\hline
\end{tabular}

a)

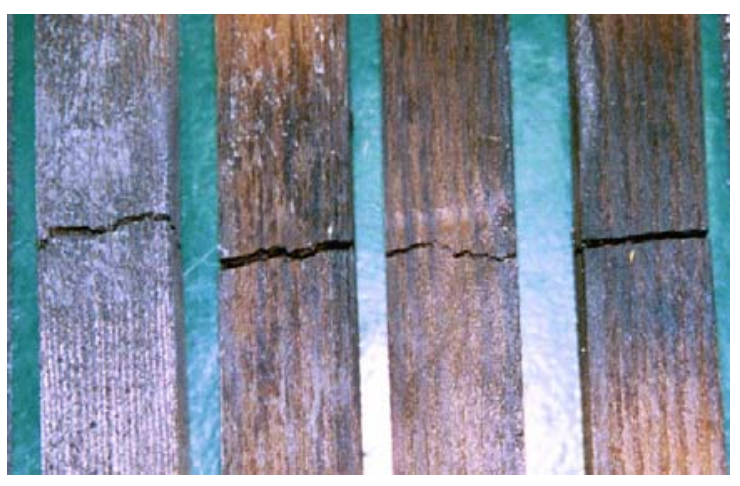

b)

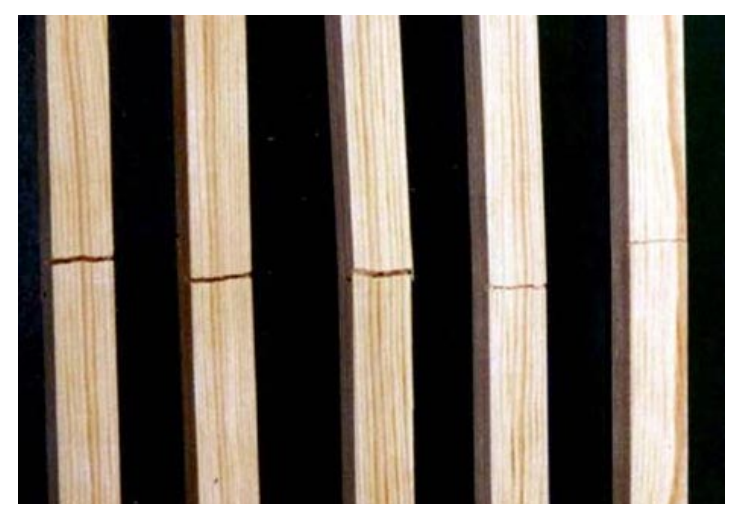

Fig 12. Smooth fractures of impregnated samples after static bending tests: a) at $230{ }^{\circ} \mathrm{C}$; b) at $20{ }^{\circ} \mathrm{C}$

a)

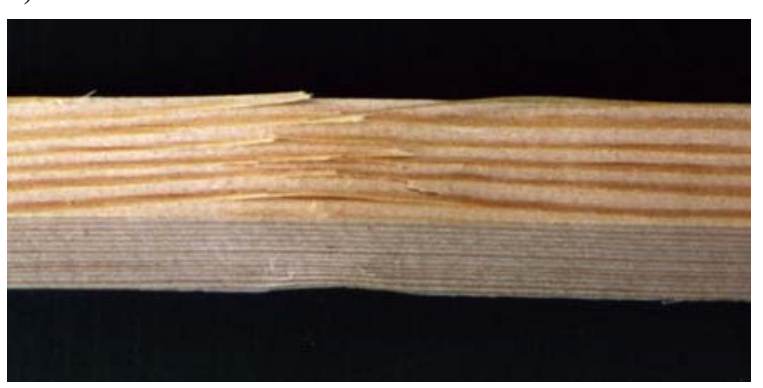

b)

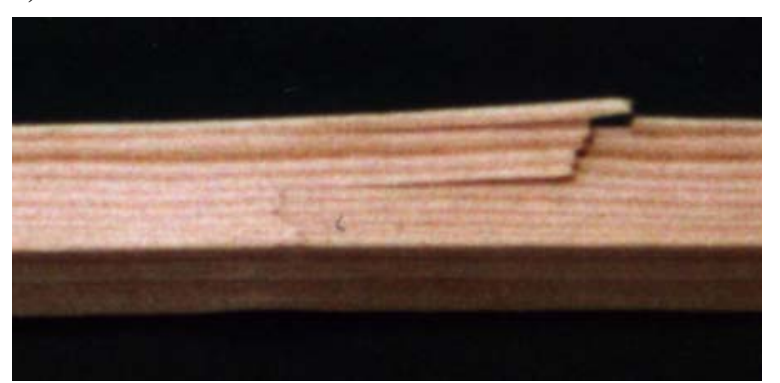

Fig 13. Long-fibre fractures of natural samples after static bending tests: a) at $20{ }^{\circ} \mathrm{C}$; b) at $200{ }^{\circ} \mathrm{C}$

a)

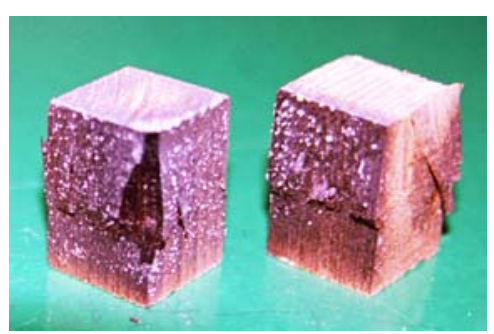

b)

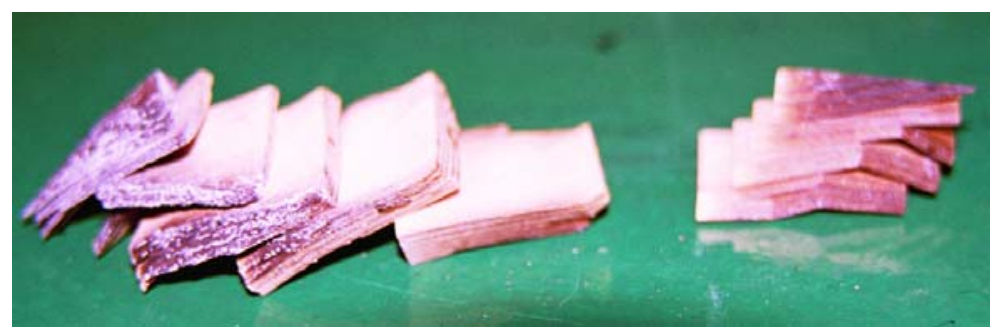

Fig 14. Damage character for impregnated samples after compressive strength tests above $200{ }^{\circ} \mathrm{C}$ :

a) carbonated fragments chipped off, impregnant efflorescence $\left(230^{\circ} \mathrm{C}\right.$ test $)$, b) sample foliation $\left(200{ }^{\circ} \mathrm{C}\right.$ test $)$ 
4. At the same time we noticed during the tests that for the same environmental conditions and for both impregnated and non-impregnated samples the moisture content did not equalise. For samples stored for 18 months at $20{ }^{\circ} \mathrm{C}$ and $45 \%$ humidity, the moisture content metered after the tests showed: the moisture content $8,5 \%$ for non-impregnated samples or $10,5 \%$ for the impregnated ones. Other researchers confirm this observation for moisture metered after storing for 60 months.

\section{Conclusions}

The impregnation with the salt-containing agent by the vacuum-and-pressure method makes a significant effect on wood strength parameters. The strength has a tendency towards decreasing. This tendency results from the wood structure damage due to: the operation of variable pressure (negative pressure/vacuum, positive pressure) in the impregnation chamber and using the saltcontaining impregnation agent.

Based on the analysis of test results and on literature regarding impregnation issues, a statement may be made that the favourable results of the vacuum-and-pressure impregnation (ie decreased wood inflammability and combustibility) are accompanied by some unfavourable phenomena such as decreased strength and impact strength, and brittleness. Due to that, also other fire protection methods for timber structures should be analysed for possibility of application.

A decreased wood strength should be considered for timber structures when applying the vacuum-and-pressure impregnation. This reservation mainly regards structures under dynamic loads.

\section{References}

1. PN-72/C-04907. Wood preservatives - Determination of effect to wood strength properties. Polish Committee for Standardization, Warszawa, 1972. 2 p. (in Polish).

2. BARISKA, M. Zur dynamischen Torsionelastizität von Holz. Teil 1: Untersuchungen im Temperaturbereich von 23 bis $350^{\circ} \mathrm{C}$. Teil 2: Zyklische Temperaturbelastung von Holz. Holz als Roh- u. Werkstoff, 1983, 41, S. 109-114, 203-209.

3. BURMESTER, A.; BECKER G. Untersuchungen über den Einfluss vor Holzschutzmitteln auf die Holzfestigkeit. Holz als Roh- $u$. Werkstoff, 1963, 21, S. 393-409.

4. GILLWALD, W. Der Einfluss verschiedener Imprägniermittel auf die physikalischen und Festigkeitseigenschften des Holzes. Holztechnologie, 1961, 2, S. 4-16.

5. LEVAN, S. L.; WINANDY, J. E. Effects of fire retardant treatments on wood strength: A Reviev. Wood and Fiber Science, 1990, 22 (1), p. 113-131.

6. LUTOMSKI, K. Influence of wood treatment conditions using hot and cold bath containing impregnation salt water solutions on pine wood static bending. Fasciles of $\mathrm{Ag}$ - ricultural Sciences Research (Zeszyty Problemowe Postępów Nauk Rolniczych), 1976, 178, p. 143-151 (in Polish).

7. WAŻNY, J. Investigation of the influence of wood preservation on strength of wood. In Proc of Conference Wood and Environment (Dreviesiny i sreda). Sofia, 1973, p. $181-185$.

8. WAŻNY, J.; KRAJEWSKI, K. Untersuchung über den Einfluss von Holzschutzmitteln auf die Druck - und Biegefestigkeit des Kiefernholzes. Holztechnologie, 1987, 28, S. 239-243.

9. WINANDY, J. E.; BENDTSEN, B. A.; BOONE R. S. Effect of delay between treatment and drying on toughness of CCA - treated southern pine. Forest Products Journal, 1983,33 , p. $53-58$.

10. WYTWERT, T. Influence of salt containing agents on wood strength against compression. Folia Forestalia Polonica, 1989, 20, p. 20.

11. PN-77/D-04227. Wood - General guidelines for sampling and specimen preparation. Polish Committee for Standardization, Warszawa, 1977. 4 p. (in Polish).

12. BEDNAREK, Z.; KALISZUK-WIETECKA, A. Scientific research on the influence of fireproof wood preservation carried out by the vacuum-pressure metod on strength of wood in normal and elevated temperatures. In Proc of the 8th International Conference "Modern Building Materials, Structures and Techniques", Vilnius, 19-22 May 2004. Selected papers, ed. E. K. Zavadskas, P. Vainiūnas and F. M. Mazzolani. Vilnius: Technika, 2004, p. 963-967.

13. BEDNAREK Z.; KALISZUK-WIETECKA A. Strength of wood impregnated by a fire protection salt containing agent made by a vacuum-and-pressure method. In Proc of the $50^{\text {th }}$ Scientific Conference Krynica 2004. Research Problems of Civil Engineering, Krynica, Poland, 12-17 Sept 2004, p. 21-26 (in Polish).

14. PN-81/D-04107. Wood - Determination of tensile strength parallel to grain. Polish Committee for Standardization, Warszawa, 1981. 2 p. (in Polish).

15. PN-77/D-04229. Wood - Determination of compressive strength perpendicular to grain. Polish Committee for Standardization, Warszawa, 1977. 3 p. (in Polish).

16. PN-79/D-04102. Wood - Determination of compressive strength parallel to grain. Polish Committee for Standardization, Warszawa, 1979. 2 p. (in Polish).

17. PN-77/D-04103. Wood - Determination of static bending strength. Polish Committee for Standardization, Warszawa, 1977. 2 p. (in Polish).

18. BEDNAREK, Z.; KALISZUK-WIETECKA, A. Research on vacuum and pressure impregnation influence on wood strength. Engineering and Building (Inżynieria $i$ Budownictwo), 2004, 4, p. 213-215 (in Polish).

19. BEDNAREK, Z.; KALISZUK-WIETECKA, A.; WIŚNIEWSKI, T. Research on the influence of fire protection impregnation carried out by the vacuum -and-pressure method on wood dynamic strength. Building Review (Przeglad Budowlany), 2002, 10, p. 12-14 (in Polish).

20. PN-79/D-04104. Wood - Determination of impact bending strength and dynamic bending strength. Polish Committee for Standardization, Warszawa, 1979. 2 p. (in Polish). 


\section{GAISRO IZOLIACIJOS ITAKOS MEDIENOS STIPRIUI ANALIZ}

\section{Z. Bednarek, A. Kaliszuk-Wietecka}

Santrauka

Pateikiami druskos turinčia medžiaga įmirkytos medienos stiprio tyrimų rezultatai ir jų analiz . Mediena impregnuota vakuuminiu-giluminiu būdu. Atlikus bandymus normaliomis ir aukštų temperatūrų sąlygomis, nustatyta, kad abiem atvejais tiriama gaisro apsaugos priemon turi didelę itaką lenkiamajam stipriui bandant statine, dinamine ir smūgine apkrovomis, taip pat stipriui tempiant bei gniuždant išilgai, skersai sluoksnių.

Reikšminiai žodžiai: mediena, stipris, aukštos temperatūros, apsauga nuo gaisro, vakuuminis-giluminis impregnavimas.

Zoja BEDNAREK. Prof Dr Sc. Rector of the Main School of Fire Service in Warsaw, Poland. Member of PN-TTE Polish Maintenance Society. Her research deals with the problems of materials and building structural strength and behaviour at high temperatures. Promoter of Doctoral thesis concerning the problems mentioned above.

Agnieszka KALISZUK-WIETECKA. PhD, academical teacher of building physics at the Warsaw Technical University, Poland. Member of Energetic Auditors Association. Her research interests include also the influence of fireproof wood preservation on strength of wood under normal and elevated temperatures, particularly carried out by the vacuum-pressure method. 